University of Nebraska - Lincoln

DigitalCommons@University of Nebraska - Lincoln

USDA National Wildlife Research Center - Staff Publications
U.S. Department of Agriculture: Animal and Plant Health Inspection Service

2012

\title{
Historical And Current Status Of Laughing Gulls Breeding In New York State
}

Brian E. Washburn

United States Department of Agriculture, brian.e.washburn@aphis.usda.gov

Martin S. Lowney

USDA, Wildlife Services, martin.s.lowney@aphis.usda.gov

Allen L. Gosser

USDA, Wildlife Services, allen.I.gosser@aphis.usda.gov

Follow this and additional works at: https://digitalcommons.unl.edu/icwdm_usdanwrc

Washburn, Brian E.; Lowney, Martin S.; and Gosser, Allen L., "Historical And Current Status Of Laughing Gulls Breeding In New York State" (2012). USDA National Wildlife Research Center - Staff Publications. 1211.

https://digitalcommons.unl.edu/icwdm_usdanwrc/1211

This Article is brought to you for free and open access by the U.S. Department of Agriculture: Animal and Plant Health Inspection Service at DigitalCommons@University of Nebraska - Lincoln. It has been accepted for inclusion in USDA National Wildlife Research Center - Staff Publications by an authorized administrator of DigitalCommons@University of Nebraska - Lincoln. 


\title{
HISTORICAL AND CURRENT STATUS OF LAUGHING GULLS BREEDING IN NEW YORK STATE
}

\author{
BRIAN E. WASHBURN, ${ }^{1,3}$ MARTIN S. LOWNEY, ${ }^{2}$ AND ALLEN L. GOSSER ${ }^{2}$
}

\begin{abstract}
The Laughing Gull (Leucophaeus atricilla) was extripated as a breeding bird from New York State by 1900. Recolonization of coastal New York by this colonial waterbird occurred in 1979 with discovery of 15 breeding pairs in Jamaica Bay (Queens County) New York, New York. We conducted a survey of Long Island salt marsh habitats in 2008 to document if other breeding colonies of Laughing Gulls existed. We identified 66 individual possible breeding areas and field surveys were conducted in each area during June 2008. Many areas appeared to provide suitable nesting habitat (i.e., large areas of salt marsh dominated by Spartina), but no evidence of Laughing Gull nesting was found. A better understanding of Laughing Gull populations within the northeast coastal region and the effects of ongoing gull control near New York airports is needed for their conservation. Received 26 September 2011. Accepted 22 March 2012.
\end{abstract}

The Laughing Gull (Leucophaeus atricilla) has a predominantly southern breeding range, extending from the Carribbean and the Gulf of Mexico northward to Atlantic Canada (Burger 1996). Few nesting colonies of Laughing Gull exist north of New Jersey along the Atlantic Coast of North America. Those few colonies are in New York, Massachusetts, Maine, and Nova Scotia (Nisbet 1971, Belant and Dolbeer 1993, Burger 1996). Nesting habitat for Laughing Gulls varies across their breeding range. They nest on sandy beaches with varying amounts of vegetation from Florida to North Carolina (Bent 1921, Burger and Gochfeld 1985). This species is a salt marsh obligate nester in the mid-Atlantic region (Virginia to New York) with colony sites exclusively in salt marsh habitats (Burger and Shisler 1978, Montevecchi 1978, Burger and Shisler 1980). Laughing Gulls nest on rocky islands with grassy areas in northern New England (Nisbet 1971).

The Laughing Gull was historically confined to the coastal areas of Long Island in New York State. This gull was a common summer resident and breeder during the early 1800s (Giraud 1844, Griscom 1923). Populations of Laughing Gulls, similar to other colonial seabirds, were decimated by commercial egging and plume-hunting for the millinery trade in the mid- to late 1800 s (Nisbet 1971, Buckley et al. 1978, Brinker et al. 2007), and the species was extirpated as a breeding bird from New York State by 1900. The last known

\footnotetext{
${ }^{1}$ USDA, Wildlife Services, National Wildlife Research Center, 6100 Columbus Avenue, Sandusky, OH 44870, USA.

${ }^{2}$ USDA, Wildlife Services, 1930 Route 9, Castleton, NY 12033, USA.

${ }^{3}$ Corresponding author; e-mail: brian.e.washburn@aphis.usda.gov
}

breeding records during that period were South Oyster Bay in 1884, Amityville in 1887, Cedar Island in 1888, and a lone pair in Orient in 1900 (Eaton 1910, Griscom 1923, Bull 1964, Latham 1975).

Laughing Gulls starting breeding (again) on Long Island in the late 1970s after an absence from New York State as a breeding bird for almost $80 \mathrm{yrs}$ (Buckley et al. 1978, Post and Riepe 1980). Our study objectives were to: (1) review and summarize information regarding Laughing Gull nesting in New York State since 1900, and (2) provide a current assessment of the distribution and the nesting status of Laughing Gulls in New York.

\section{METHODS}

Breeding Records.-We reviewed the scientific literature, books, published reports, and other printed materials for any and all available records and information regarding the breeding status of Laughing Gulls in New York State from the 1800s to 2008. We contacted curatorial staff or accessed on-line data bases for the New York State Breeding Bird Atlas, the USGS Breeding Bird Survey (BBS), and the New York eBird Network. Reports and data summaries of Long Island Colonial Waterbird and Piping Plover (Charadrius melodus) Survey information were obtained from the New York State Department of Environmental Conservation (NYSDEC). Personal and telephone interviews were conducted with representatives from the NYSDEC, National Park Service, U.S. Fish and Wildlife Service, Town of Hempstead, New York City Audubon, and other entities. All breeding records and associated information were compiled into an electronic data base, which we used for the summary and analysis of Laughing Gulls breeding in New York 


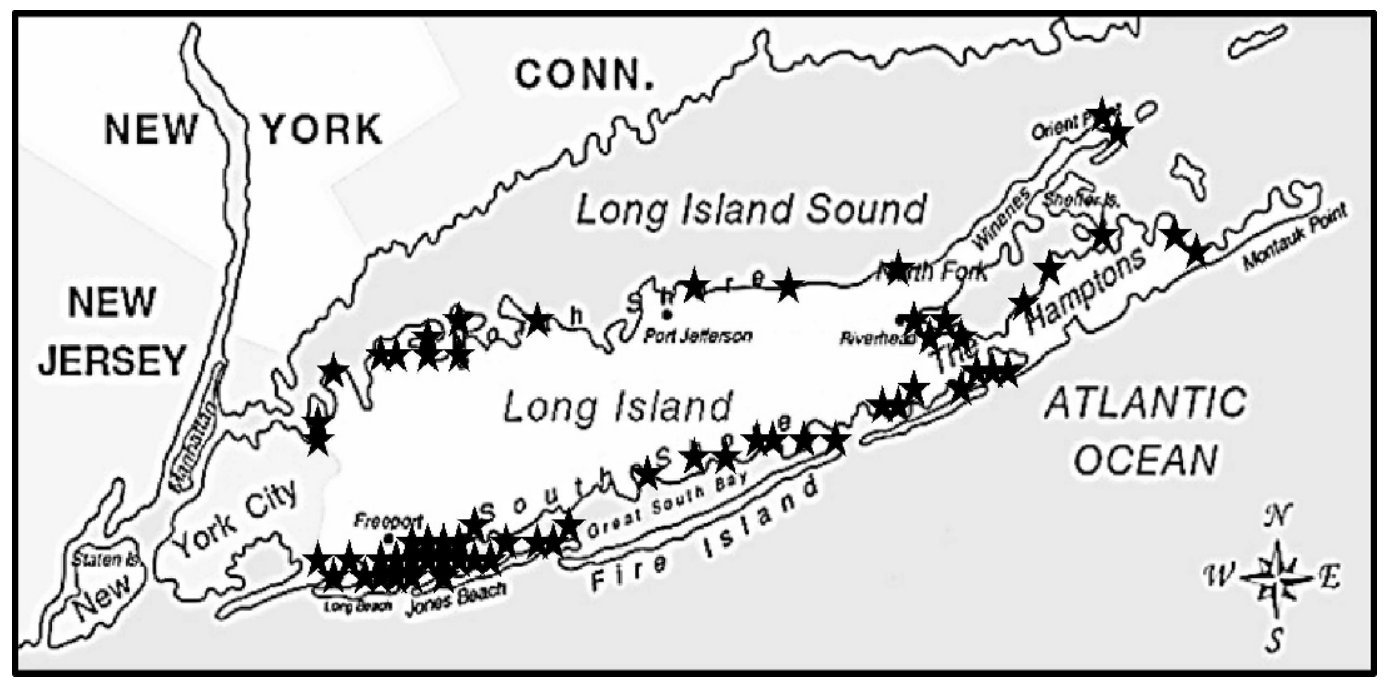

FIG. 1. Areas $(n=66)$ on Long Island, New York, searched in June 2008, representing potential nesting locations of Laughing Gulls.

(objective 1) and for selecting potential sites to examine for presence of Laughing Gulls (objective 2).

We obtained the New York State Official Tidal Wetlands Inventory from the NYSDEC. Georeferenced salt marsh maps for Long Island were extracted using GIS (ArcGIS 9.2; ESRI, Redlands, CA, USA). These maps provided an estimate of all salt marsh intertidal zone habitats available to nesting Laughing Gulls. Much of the $\sim 445 \mathrm{~km}$ of Long Island's shoreline is developed, although coastal wetland habitats (e.g., salt marsh) remain in some areas (Gornitz et al. 2002). The largest concentrations of intertidal salt marsh occur on the south shore, although small areas occur on the north shore.

We combined all records (e.g., Laughing Gull nesting records, observations, and salt marsh inventory) into a spatially-referenced electronic data base using GIS. We identified and selected 66 individual sites that represented potential locations where Laughing Gulls might be nesting on Long Island based on the information in our electronic data base (Fig. 1).

Field Surveys.-We conducted field surveys during daylight hours at all 66 individual sites (Fig. 1) during 9-20 June 2008. We chose this time period to coincide with the expected peak nesting period for Laughing Gulls (Montevecchi et al. 1979, Burger 1996). Two or more trained individuals systematically observed all visible habitats during the survey at each location with the aid of binoculars and spotting scopes from all available vantage points. The number of Laughing Gull nests, number of Laughing Gulls observed by age class (individual Laughing Gulls were assigned to age classes based on plumage [Belant and Dolbeer 1996]), and specific activities of all Laughing Gulls observed were recorded during each field survey. General observations were recorded regarding the presence/absence of salt marsh habitat, Spartina, and the perceived potential value of the location for nesting by Laughing Gulls based on the characteristics of the vegetation and hydrology.

\section{RESULTS}

We found no records or information to verify that Laughing Gulls were actively breeding in the State of New York from 1900 to the late 1970s (Eaton 1910, Griscom 1923, Bull 1964). However, accounts from this period suggested large numbers of Laughing Gulls in breeding plumage were observed on Long Island (Griscom 1923, Cruickshank 1942, Bull 1964).

Laughing Gulls began breeding (again) in New York State during the late 1970s after a nearly 80year absence, Buckley et al. (1978) reported the first breeding record of Laughing Gulls in the state since 1900 in Nassau County (Fig. 2). Post and Riepe (1980) found a Laughing Gull nesting colony (15 pairs) in 1978 in the Joco Marsh island 


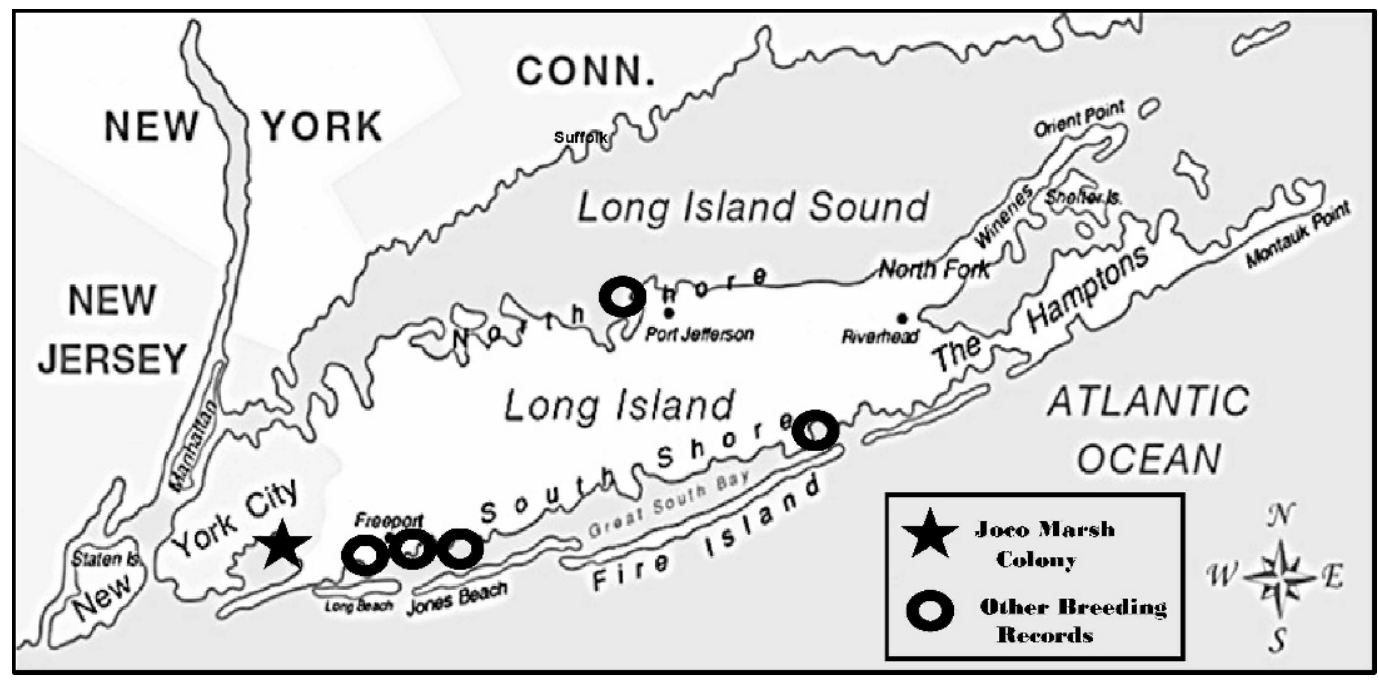

FIG. 2. Known Laughing Gull nesting sites in New York State during 1901-2008.

complex $\left(40^{\circ} 38^{\prime} \mathrm{N}, 73^{\circ} 47^{\prime} \mathrm{W}\right)$ in the Jamaica Bay Unit of the Gateway National Recreation Area in Queens County (Fig. 2). This colony increased exponentially to an estimated 7,629 nests in 1990 (Brown et al. 2001). The Laughing Gull nesting colony in Jamaica Bay (several islands in Jamaica Bay in primarily intertidal low or high salt marsh) decreased by $83 \%$ during 1992-2008 to an estimated 1,280 nests in 2008 (Washburn et al. 2009). This nesting colony is influenced by an integrated gull strike management program conducted on the adjacent John F. Kennedy International Airport (Washburn et al. 2008), and loss of nesting habitat due to severe marsh erosion and tidal flooding (Gornitz et al. 2002, Hartig et al. 2002, Boger et al. 2012).

Over $99.9 \%$ of the Laughing Gulls nesting in New York was associated with the nesting colony in Jamaica Bay during 1978-2007. Six additional breeding records of Laughing Gulls were found outside of Jamaica Bay (Table 1, Fig. 2). These sites were abandoned by nesting Laughing Gulls after 1 or 2 yrs as no additional Laughing Gull nests were found during surveys in subsequent years (Sommers et al. 1994, 1996, 2001).

We found no Laughing Gull nests or evidence of Laughing Gulls breeding during field surveys at 66 potential locations we surveyed. Seventytwo Laughing Gulls (66 adults in breeding plumage and 6 subadults) were observed during the surveys, ranging from 0 to 30 individual gulls per survey location. Laughing Gulls were observed loafing or perched (47\%), feeding (29\%), and flying $(24 \%)$, but we did not observe any activity that suggested these birds were nesting or near a breeding colony.

Fifty-three of 66 locations surveyed (80\%) contained salt marsh habitat, of which 44 were classified as low salt marshes (dominated by Spartina alterniflora) and nine sites were high salt marsh habitat (predominantly S. patens). Common reed (Phragmites australis) had invaded 12 of the $66(18 \%)$ salt marsh areas, degrading their ecological value and making them relatively useless for nesting Laughing Gulls.

\section{DISCUSSION}

Review of historical information, peer-reviewed literature, reports, and unpublished information confirms the Laughing Gull was a breeding bird in New York State (more specifically on Long Island) during 1978-2008. Our findings suggest the Laughing Gull nesting colony in Jamaica Bay was likely the only nesting colony in New York in 2008.

Laughing Gull populations are relatively stable or increasing within the Northeast region and nationally in the United States, based on population trends from the BBS (Sauer et al. 2011) and nest counts within coastal states from New Jersey to Maine (summarized in Washburn et al. 2009). The overall population index for Laughing Gulls in the United States and in the Northeastern/MidAtlantic Region during 1966-2009 showed mean 
TABLE 1. Laughing Gull breeding records in New York State during 1978-2007 not associated with the nesting colony in Jamaica Bay, New York.

\begin{tabular}{lllll}
\hline Year & \multicolumn{1}{c}{ Location (Coordinates) } & County & Number of nests \\
\hline 1978 & Line Island complex $\left(40^{\circ} 36^{\prime} \mathrm{N}, 73^{\circ} 36^{\prime} \mathrm{W}\right)$ & Nassau & 1 & Buckley et al. (1978) \\
1990 & North Cinder Island $\left(40^{\circ} 36^{\prime} \mathrm{N}, 73^{\circ} 29^{\prime} \mathrm{W}\right)$ & Nassau & 4 & Sommers et al. (1994) \\
1991 & North Cinder Island $\left(40^{\circ} 36^{\prime} \mathrm{N}, 73^{\circ} 29^{\prime} \mathrm{W}\right)$ & Nassau & 4 & Sommers et al. (1994) \\
1995 & Young's Island $\left(40^{\circ} 55^{\prime} \mathrm{N}, 73^{\circ} 09^{\prime} \mathrm{W}\right)$ & Suffolk & 2 & Sommers et al. (2001) \\
1998 & Carter's Island $\left(40^{\circ} 45^{\prime} \mathrm{N}, 72^{\circ} 48^{\prime} \mathrm{W}\right)$ & Suffolk & 5 & Sommers et al. (2001) \\
2007 & Tobay Marsh Islands $\left(40^{\circ} 37^{\prime} \mathrm{N}, 73^{\circ} 25^{\prime} \mathrm{W}\right)$ & Nassau & 4 & S. P. Sinkevich, pers. comm. \\
\hline
\end{tabular}

annual increases of 4.5 and $5.8 \%$, respectively (Sauer et al. 2011).

The presence of adult Laughing Gulls in breeding plumage within apparently suitable habitat is not a direct indication of the presence of a nesting colony. Dolbeer and Bernhardt (2003) reported $46 \%$ of 2 -year-old and $12 \%$ of $\geq 3$-yearold female Laughing Gulls in breeding plumage showed no evidence of reproduction. Non-breeding gulls could be using salt marsh habitats for foraging during summer months. The presence of hatching-year Laughing Gulls on Long Island during late summer and early fall does not necessarily indicate the presence of breeding, as northward movements prior to fall migration have been noted (Burger and Galli 1986, Belant and Dolbeer 1993).

Salt marsh habitats on Long Island appear to provide suitable nesting habitat for Laughing Gulls. Large, open tidal areas dominated by Spartina and lacking woody vegetation and common reed occurred in numerous locations along the coast of Long Island. However, the reason(s) why Laughing Gulls are not nesting on Long Island in areas outside of Jamaica Bay are unknown. Herring Gulls (Larus argentatus) might be a problem within areas along the Long Island shoreline where this species is nesting, as breeding Laughing Gulls have been displaced by Herring Gulls (Burger and Shisler 1978, Burger 1996). Human disturbance and mammalian predators could also be reducing the quality of salt marsh habitats for Laughing Gulls and other colonial seabirds (Burger and Shisler 1980, Buckley and Buckley 2000).

Erosion and degradation of salt marshes is a significant problem along the east coast of the United States (Gornitz et al. 2002, Hartig et al. 2002, Boger et al. 2012). Loss of coastal wetland habitats impacts a variety of colonial nesting waterbirds, including Laughing Gulls (Erwin et al.
2006, Brinker et al. 2007). Degradation of salt marsh habitat along Long Island could negatively impact the existing nesting colony in Jamaica Bay, and reduce the number and quality of other potential nesting locations.

Common reed commonly invades salt marsh habitats along the Atlantic Coast and in wetland areas along the Great Lakes, converting native plant communities into dense monotypic stands and altering the structure and function of these areas (Roman et al. 1984, Silliman and Bertness 2004). Expansion of common reed into wetland habitats decreases bird diversity and negatively impacts marsh-nesting songbirds and waterbirds (Benoit and Askins 1999, Wells et al. 2008). The invasion of salt marsh habitats along Long Island by common reed is an important concern, reducing available nesting habitat for Laughing Gulls (New York Natural Heritage Program 2011).

The Jamaica Bay colony contains $>99 \%$ of the Laughing Gulls nesting in New York State. This colony is influenced by an integrated gull strike management program at John F. Kennedy International Airport (Washburn et al. 2009), severe erosion and tidal flooding of salt marshes in Jamaica Bay (Hartig et al. 2002), and high levels of pollutants and contaminants in Jamaica Bay waters (Seidemann 1991). The nesting colony of Laughing Gulls remained viable and relatively stable in size during 2000-2008 despite the removal of $>88,000$ Laughing Gulls during 1991-2008 as part of the integrated gull strike management program (Washburn et al. 2008, Washburn et al. 2009), and concurrent severe habitat loss due to tidal flooding and marsh erosion (Gornitz et al. 2002, Hartig et al. 2002, Boger et al. 2012). However, one extreme weather event (e.g., hurricane) could completely degrade the salt marshes in Jamaica Bay (Gornitz et al. 2002) and remove this nesting site for Laughing 
Gulls while simultaneously decreasing potential Laughing Gull-aircraft collisions.

\section{CONSERVATION IMPLICATIONS}

The presence of well dispersed Laughing Gull nesting colonies in New York State is an important conservation concern (New York Natural Heritage Program 2011). We suggest efforts should be conducted to establish other nesting colonies on Long Island. Laughing Gull nesting could be encouraged through active management activities (e.g., gull decoys, calls, and nest placement) following identification of suitable nesting habitats in existing salt marshes. This possibility should be considered by the appropriate wildlife management agencies.

\section{ACKNOWLEDGMENTS}

We thank L. A. Tyson, L. A. Humberg, J. J. Albanese, D. R. Nicolay, and others for field assistance. We appreciate the data and information provided by many individuals from several agencies and groups. Financial and logistical support for this project was provided by the Port Authority of New York and New Jersey, and USDA Wildlife Services. This research was approved by the National Wildlife Research Center IACUC (QA-1131).

\section{LITERATURE CITED}

Belant, J. L. AND R. A. DolbeER. 1993. Population status of nesting Laughing Gulls in the United States 19971991. American Birds 47:220-224.

Belant, J. L. AND R. A. DOlBEER. 1996. Age classification of Laughing Gulls based on summer plumage. Journal of Field Ornithology 67:565-574.

BenoIT, L. K. AND R. A. AsKins. 1999. Impact of the spread of Phragmites on the distribution of birds in Connecticut tidal marshes. Wetlands 19:194-208.

BENT, A. C. 1921. Life histories of North American gulls and terns. U.S. National Museum Bulletin 113:165175.

Boger, R., J. Connolly, and M. Christiano. 2012. Estuarine shoreline changes in Jamaica Bay, New York City: implications for management of an urban national park. Environmental Management 49:229-241.

Brinker, D. F., J. M. McCanN, B. Williams, AND B. D. WATTS. 2007. Colonial-nesting seabirds in the Chesapeake Bay Region: where have we been and where are we going? Waterbirds 30 (Special Publication 1):93104.

Brown, K. M., J. L. Tims, R. M. ERwin, AND M. E. RICHMOND. 2001. Changes in the nesting populations of colonial waterbirds in Jamaica Bay Wildlife Refuge, New York, 1974-1998. Northeastern Naturalist 8:275-292.

Buckley, F. G., M. Gochfeld, AND P. A. BuCKLey. 1978. Breeding Laughing Gulls return to Long Island. Kingbird 28:202-207.
Buckley, P. A. And F. G. Buckley. 2000. Patterns of colony-site use and disuse in saltmarsh-nesting Common and Roseate terns. Journal of Field Ornithology 71:356-369.

BuLl, J. 1964. Birds of the New York area. Harper and Row, New York, USA.

BURGER, J. 1996. Laughing Gull (Larus atricilla). The birds of North America. Number 225.

Burger, J. AND J. GALLI. 1986. Factors affecting the distribution of gulls (Larus spp.) on two New Jersey coastal bays. Environmental Conservation 13:59-65.

BURGER, J. AND M. GOCHFELD. 1985. Nest site selection by Laughing Gulls: comparison of tropical colonies (Culebra, Puerto Rico) with temperate colonies (New Jersey). Condor 87:364-373.

Burger, J. AND J. SHISLER. 1978. Nest site selection and competitive interactions of Herring and Laughing gulls in New Jersey. Auk 95:252-266.

Burger, J. AND J. Shisler. 1980. Colony and nest site selection in Laughing Gulls in response to tidal flooding. Condor 82:251-258.

Cruickshank, A. D. 1942. Birds around New York City. Handbook Series Number 13. American Museum of Natural History, New York, USA.

Dolbeer, R. A. AND G. E. Bernhardt. 2003. Age-specific reproduction by female Laughing Gulls (Larus atricilla). Auk 120:531-535.

EATON, E. H. 1910. Birds of New York. New York State Museum Memoir 12. University of the State of New York, Albany, USA.

Erwin, R. M., G. M. SAnders, D. J. Prosser, AND D. R. CAHOON. 2006. High tides and rising seas: potential effects on estuarine waterbirds. Studies in Avian Biology 32:214-228.

Giraud, J. P. 1844. Birds of Long Island. Wiley and Putnam, New York, USA.

Gornitz, V., S. Couch, AND E. K. HARTwig. 2002. Impacts of sea level rise in the New York City metropolitan area. Global and Planetary Changes 32:61-88.

GrisCOM, L. 1923. Birds of the New York City region. Handbook Series Number 9. American Museum of Natural History, New York, USA.

Hartig, E. K., V. Gornitz, A. Kolker, F. Mushacke, AND D. FALLON. 2002. Anthropogenic and climatechange impacts on salt marshes of Jamaica Bay, New York City. Wetlands 22:71-89.

LATHAM, R. 1975. Laughing Gulls, Larus atricilla, nesting at Orient, Long Island. Pitch Pine Naturalist 3:3-4.

MonteVeCCHI, W. A. 1978. Nest site selection and its survival value among Laughing Gulls. Behavior, Ecology, and Sociobiology 4:143-161.

Montevecchi, W. A., M. Impekoven, A. Segre-Terkel, AND C. G. BEER. 1979. The seasonal timing and dispersion of egg-laying among Laughing Gulls Larus atricilla. Ibis 121:337-344.

New York Natural Heritage Program. 2011. Conservation guide for Laughing Gull (Leucophaeus articilla). Albany, New York, USA. http://www.acris. nynhp.org/guide.php?id $=6897$

NisBet, I. C. T. 1971. The Laughing Gull in the Northeast. American Birds 25:677-683. 
Post, P. W. AND D. RIEPE. 1980. Laughing Gulls colonize Jamaica Bay. Kingbird 30:11-13.

Roman, C. T., W. A. Niering, and R. S. Warren. 1984. Salt marsh vegetation change in response to tidal restriction. Environmental Management 8:141-150.

Sauer, J. R., J. E. Hines, AND J. Fallon. 2011. The North American Breeding Bird Survey, results and analysis 1966-2009. Version 3.23.2011, USGS, Patuxent Wildlife Research Center, Laurel, Maryland, USA. www.mbr-pwrc.usgs.gov

SeIdemanN, D. E. 1991. Metal pollution in sediments in Jamaica Bay, New York, USA - an urban estuary. Environmental Management 15:73-81.

Silliman, B. R. AND M. D. Bertness. 2004. Shore development drives invasion of Phragmites australis and the loss of New England salt marsh plant diversity. Conservation Biology 18:1424-1434.

Sommers, L. A., D. L. Rosenblatt, AND M. J. DelPeurto. 2001. 1998-1999 Long Island Colonial Waterbird and Piping Plover Survey. New York State Department of Environmental Conservation, Stony Brook, USA.

Sommers, L. A., R. Miller, K. J. Meskill, and M. L. ALFIERI. 1994. 1992-1993 Long Island Colonial Waterbird and Piping Plover Survey. New York State
Department of Environmental Conservation, Stony Brook, USA.

Sommers, L. A., M. L. Alfieri, K. J. Meskill And R. MILLER. 1996. 1995 Long Island Colonial Waterbird and Piping Plover Survey. New York State Department of Environmental Conservation, Stony Brook, USA.

Washburn, B. E., R. A. Dolbeer, G. E. Bernhardt, AND L. A. TYSON. 2008. Laughing Gull nest population in Jamaica Bay, New York, 1992-2008. Special Report for the Port Authority of New York and New Jersey. USDA, Wildlife Services, National Wildlife Research Center, Sandusky, Ohio, USA.

Washburn, B. E., B. N. Haslun, M. S. Lowney, and S. E. TENNIS. 2009. Shooting gulls to reduce strikes with aircraft at John F. Kennedy International Airport, 1991-2008. Special Report for the Port Authority of New York and New Jersey. USDA, Wildlife Services, National Wildlife Research Center, Sandusky, Ohio, USA.

Wells, A. W., W. C. Nieder, B. L. SWift, K. A. O'CONNER, AND C. A. WeIss. 2008. Temporal changes in the breeding bird community at four Hudson River tidal marshes. Journal of Coastal Research 55:221-235. 